\title{
Predisposing Factors of Complementary Feeding Practices among 9-11 Month-Old Infants in Jakarta Urban Slum Area
}

\author{
Faktor-faktor Predisposisi pada Praktik Pemberian Makanan Pendamping \\ Air Susu Ibu pada Bayi Usia 9-11 Bulan di Daerah Kumuh Perkotaan Jakarta
}

Septriana*, Gita Ardelia Suhartono**

*Nutrition Studies, Faculty of Health Sciences, Universitas Respati Yogyakarta, Yogyakarta, Indonesia, **Nutrition Studies, Sint Carolus School of Health Sciences, Jakarta, Indonesia

DOI: http://dx.doi.org/10.21109/kesmas.v10i3.948

\begin{abstract}
The main cause of the undernutrition beside the infectious diseases is inappropriate caring practice and optimum feeding becomes one of ways to overcome long-term consequences of undernutrition. This study aimed to determine correlation between predisposing factors with complementary feeding practice among 9 - 11 month-old infants in Jakarta urban slum area. This cross-sectional study included 50 sitters of $9-11$ month-old infants on May 2012. Data was collected through interview using questionnaire. There was no significant correlation between age of the sitters with the complementary feeding practice ( $p$ value $=0.645$ ) as well as correlation between sitters with infants ( $p$ value $=0.724)$, occupation of sitters ( $p$ value $=1.000$ ) and the number of infants in a family ( $p$ value $=0.738$ ) which showed there was no significant correlation between those three factors with complementary feeding practice. Otherwise, there was a significant correlation between education and knowledge of sitters with complementary feeding practice ( $p$ value $=0.012$ and $p$ value $=0.005$ )

Keywords: Feeding practice, infants aged $9-11$ months old, urban slum area

\footnotetext{
Abstrak

Penyebab utama kekurangan gizi selain dari penyakit infeksi adalah pola asuh yang tidak sesuai dan pemberian makan yang optimal menjadi salah satu cara untuk mengatasi konsekuensi jangka panjang dari kekurangan zat gizi. Penelitian ini bertujuan untuk mengetahui hubungan antara faktor pendukung praktik pemberian makanan pendamping air susu ibu (MPASI) pada bayi usia 9 - 11 bulan di daerah kumuh perkotaan Jakarta. Penelitian potong lintang ini melibatkan 50 orang pengasuh bayi usia 9 - 11 bulan. Data dikumpulkan melalui wawancara menggunakan kuesioner. Tidak terdapat hubungan yang bermakna antara usia pengasuh dengan praktik pemberian makan (nilai $p=0,645$ ). Demikian juga dengan hubungan antara
}

pengasuh dengan bayi (nilai $p=0,724$ ), pekerjaan pengasuh (nilai $p=$ 1,000 ), dan jumlah bayi dalam satu keluarga (nilai $p=0,738$ ) yang menunjukkan tidak adanya hubungan antara ketiga faktor tersebut dengan praktik pemberian makanan. Sebaliknya, terdapat hubungan yang bermakna antara pendidikan dan pengetahuan pengasuh dengan praktik pemberian makanan (nilai $p=0,012$ dan nilai $p=0.005$ ).

Kata kunci: Praktik pemberian makanan, bayi usia 9 - 11 bulan, daerah kumuh perkotaan

\section{Introduction}

Undernutrition among toddlers remains a serious problem. ${ }^{1-3}$ World Health Organization (WHO) has identified poor quality and quantity of complementary food with inappropriate feeding practices as one of the major causes of undernutrition among children and the immediate consequences of poor nutrition during two years of age including significant morbidity and mortality as well as delayed mental and motor development. Poor breastfeeding and complementary feeding practices, coupled with high rates of infectious diseases, are the principal proximate causes of malnutrition during this stage of age. ${ }^{4-6}$

Adequate nutrition during infancy and early childhood is fundamental to the development of each child's full human potential. It is well recognized that the period from birth to two years of age is a 'critical window' for

Correspondence: Septriana, Nutrition Studies, Faculty of Health Sciences, Universitas Respati Yogyakarta, Tajem Main Street KM 1.5, Maguwoharjo, Yogyakarta 55282, Phone: +62 274 4437888, e-mail: sept3ana@gmail.com 
the promotion of optimal growth, health and behavioral development. ${ }^{7,8}$ Breastfeeding is enough to fulfill infants requirement until six months. However, after six months of age, breast milk itself is no longer sufficient. ${ }^{9}$ The age period is often marked by growth faltering, micronutrient deficiencies and common childhood illnesses, such as diarrhea, as children transition from exclusive breastfeeding to solid foods in addition to breast milk. ${ }^{5}$

According to The United Nations Children's Fund (UNICEF), one of the main causes of the malnutrition beside the inadequate nutrition is inappropriate caring practice. The introduction of complementary food is a critical stage. A child will be at increasing risk of malnutrition and illness if such food is introduced much more before the age of six months, or if the preparation and storage of food in the house is unhygienic. For optimum development, children require emotional support and cognitive stimulation, then parents and other sitters have a crucial role in recognizing and responding to the actions and needs of infants. ${ }^{10}$

According Kumar et al, ${ }^{11}$ improper feeding practice had significantly correlated with the toddlers' nutritional status ( $\mathrm{p}$ value $<0.05$ ). Feeding practice is influenced by education, knowledge and beliefs of the sitters. ${ }^{12}$ Appropriate feeding practices are fundamental necessity for the survival, growth, development, health and nutrition of infants and children. Some studies on complementary feeding in Indonesia revealed that complementary feeding practices were inappropriate, complementary food was introduced too early or too late and both quality of complementary food are below recommendation. ${ }^{13,14}$ The frequency and portion of food provided to the $6-23$ month-old infants were less than the recommendation. ${ }^{13}$

Infants and children are divided into three different age groups. From the first time baby was born until six months of age, this is the period of exclusive breastfeeding which means that the baby only receives breast milk as his/her food. The next six to eight months, baby starts to be introduced to food or liquid along with the breast milk. When the baby at the age of $9-11$ months, the consistency of food should be semi-solid food. This period is called special transitional food. After the children entering 12 months of their life, they start to recognize food like other members of family consume. ${ }^{15,16}$

Contribution of energy from breast milk is 413 $\mathrm{kcal} /$ day at aged of $6-8$ months and will be reduced approximately by $8 \%$ into $379 \mathrm{kcal} /$ day at the age of $9-11$ months. Thus, gap of energy needs should be filled from the complementary feeding, which the complementary feeding contributes worth $269 \mathrm{kcal}$ at the age of $6-8$ months and will be increased into $451 \mathrm{kcal}$ at the age of $9-11$ months. Meanwhile, the digestive system of infants aged $9-11$ months are still in the stage of adapt- ing the semi-solid food and provided the limited capacity of the stomach and nutrient density of complementary food. $8,17,18$

A study conducted in Aceh, Indonesia concerning complementary feeding showed that $68.2 \%$ respondents had already provided complementary food since they were less than four months old and most of infants aged 6 - 12 months were already provided home-made complementary food $(51.4 \%)$ and combination of homemade and instant ones $(35.7 \%) .{ }^{19}$

Constrain to improving feeding practice can be classified as environmental (unavailability or seasonal variability of certain food, the need to work outside the house which decreases time available for food preparation and feeding, scarcity of cooking fuel or communication of misinformation by health workers about child-feeding), or attitudinal (perceptions, beliefs, and taboos related to feeding). Frequency of feeding, especially for infants from 9 to 11 months becomes an important concern once the child has become accustomed to new food and begins to need more food to supplement breastfeeding. Because most stapple food are bulky, children need to eat more frequently than the standards two to three times per day of the adult. 20

Therefore, this study aimed to assess the correlation between predisposing factors with complementary feeding practices among 9-11 month-old infants in Indonesia, especially in Jakarta urban slum area.

\section{Method}

This study was part of the bigger study titled "Complementary Feeding Practices and Nutritional Status among 9 - 11 Month-Old Infants in Jakarta Urban Slum Area”. The study was divided into two main results which were concerning on the complementary feeding practices and nutritional status, whereas it was published elsewhere. This cross-sectional study was conducted in Senen District, Central Jakarta, Indonesia on May 2012. Purposive sampling was used based on inclusion and exclusion criteria. Inclusion criteria in this study were sitters of $9-11$ month-old infants and willing to be respondents, while the exclusion were sitters of infants with special needs or other chronic diseases. From the survey, there were 50 sitters of $9-11$ month-old infants who met the inclusion criteria.

Most interviews were conducted in integrated health care, but sometimes also in sitters' houses and in cadre's houses. Questionnaires for sitters consisted of questions on demographic data of the household including age of sitters, the correlation between sitters with infants, sitters' education, sitters' occupation, number of infants, and sitters' knowledge regarding complementary feeding. The questionnaire questioned about breastfeeding practice, complementary feeding practice, frequency of 
food provided by the sitter, child's feeding practice, the type of usual and specific food eaten by children. Based on WHO guidelines for complementary feeding, this study used five indicators to assess complementary feeding practices. Other indicators were not assessed in this study because it was assessed by other studies. To assess knowledge of sitters on complementary feeding practice, this study used three questions about continued breastfeeding, complementary feeding as well as timing and consistency of food. Predisposing factors of complementary feeding practice are factors able to influence the complementary feeding practice, such as age of sitters, relation between sitters and infants, sitters' education, sitters' occupation, amount of infants, and sitters' knowledge regarding complementary feeding.

Dependent variables in this study were the predisposing factors, while the independent variable was complementary feeding practice. Food intake data already collected by 24 hour food recall were analyzed by Nutrisurvey 2004 and continued with PC Side to determine the inadequacy of the food intake. Univariate analysis was used by frequency distribution table and percentage. Bivariate analysis was conducted by chisquare statistical analysis, odds ratio (OR) with 95\% CI, with $\mathrm{p}$ value $<0.05$ to meet the requirement of chi-square analysis. If there was a cell having expected value less than five $(20 \%)$, therefore, fisher exact statistical analysis would be used. Further multivariate analysis was conducted to analyze which factor highly predisposing the complementary feeding practice on $9-11$ month-old infants.

\section{Results}

Univariate analysis consisted of respondents' characteristics based on predisposing factors. A total number of sitters of $9-11$ month-old infants was 50 respondents. From 50 infants, there were 32 males and 18 females with the amount of subject in the range nine months of age were 16 infants. Then for group of aged 10 months and 11 months were each 17 infants.

Table 1 showed most sitters were more than 21 years old $(88 \%)$, and most of them finished their primary education $(62 \%)$. Most sitters were housewives $(82 \%)$ and about $58 \%$ sitters were only taking care of one under two year-old infant. Most of them had good complementary feeding practice $(64 \%)$.

Based on 2010 WHO guidelines of complementary feeding practice, this study found that 29 out of 50 infants $(58 \%)$ still continued to suckle, while most of those 29 infants who still continued to suckle had fulfilled the nutrient requirement of a combined group of breastfed and formula-fed infants, for instance energy intake $(90 \%)$, protein intake $(86 \%)$, iron intake $(62 \%)$ and calcium intake $(76 \%)$, except for the zinc intake $(31 \%)$.
Most sitters provided appropriate food consistency, which was semi-solid food for 9 - 11 month-old infants (74\%). About $90 \%$ infants had adequate energy intake and more than $50 \%$ infants had appropriate meal and snack frequency with dietary diversity more than four types of food $(74 \%)$. Other indicators in WHO complementary feeding guidelines were not assessed in this study. (Table 2)

Table 3 showed that there was no significant correlation between age of the sitters with the complementary feeding practice ( $\mathrm{p}$ value $=0.645$ ) as well as the correlation between the sitters with the infants $(\mathrm{p}$ value $=$ $0.724)$, sitters' occupation $(p$ value $=1.000$ ) and the amount of infants in a family ( $\mathrm{p}$ value $=0.738$ ) showing that there was no significant correlation between those factors with complementary feeding practice. On the contrary, there was significant correlation between sitters' education and knowledge with complementary feeding practice $(\mathrm{p}$ value $=0.012$ and $\mathrm{p}$ value $=0.005)$.

Based on the multivariate analysis in Table 4, it showed that sitters' education and knowledge were protective variables on complementary feeding practice (OR $=0.237$ and 0.216) which means that the mother who has higher education and better knowledge tends to perform good complementary feeding practice.

\section{Discussion}

Behavior is the totality of a person's appreciation and activity that is the result of joint or resultant between various factors, both internal and external factors. Internal factors are the characteristics of the person concerned who are given or innate, intelligence level for instance, an emotional level, gender, etc. External factors are environments, both the physical environment and social, cultural, economic, political environment, etc. Behavior are influenced by three main factors that are predisposing factors which include knowledge and people's behavior on health, tradition, and public trust on

Table 1. Nutrient Intake compared with Indonesian's RDA and Nutrient Inadequacy

\begin{tabular}{llll}
\hline Variables & Category & $\mathbf{n}$ & $\%$ \\
\hline \multirow{2}{*}{ Age of sitters } & $\leq 21$ years old & 6 & 12 \\
\multirow{3}{*}{ Relation with the infants } & $>21$ years old & 44 & 88 \\
& Mothers & 39 & 78 \\
Sitters' education & Alternate sitters & 11 & 22 \\
& > Junior high school & 19 & 38 \\
Sitters' occupation & > Senior high school & 31 & 62 \\
& Housewives & 41 & 82 \\
Amount of infants & Working mothers & 9 & 18 \\
\multirow{2}{*}{ Sitters' knowledge } & $>1$ infants & 21 & 42 \\
\multirow{2}{*}{ Complementary feeding practice } & 1 infant & 29 & 58 \\
& Less & 23 & 46 \\
& Good & 27 & 54 \\
& Good & 18 & 36 \\
& & 32 & 64
\end{tabular}


Table 2. Feeding Practices among 9 - 11 Month-Old Infants Compared to WHO Guidelines

\begin{tabular}{|c|c|c|}
\hline Guiding Principles & Indicator & n $(\%)$ \\
\hline Continued breastfeeding $(\mathrm{N}=50)$ & $\begin{array}{l}\text { Continue frequent, on-demand breastfeeding until } \\
2 \text { years of age or beyond }\end{array}$ & $29(58 \%)$ \\
\hline Amount of complementary food needed $(\mathrm{N}=29)$ & $\begin{array}{l}\text { The total energy requirements of a combined group } \\
\text { of breastfed and formula-fed infants is } 701 \mathrm{kcal} / \mathrm{d} \\
\text { at } 9-11 \text { months of age }\end{array}$ & $\begin{array}{l}\text { Energy : } 26(90 \%) \\
\text { Protein: } 25(86 \%) \\
\text { Iron: } 18(620 \%) \\
\text { Calcium : } 22(76 \%) \\
\text { Zinc : } 9(31 \%)\end{array}$ \\
\hline Food consistency $(\mathrm{N}=50)$ & $\begin{array}{l}\geq 6 \text { months : soft foods } \\
\geq 8 \text { months : semi-solid foods } \\
\geq 12 \text { months : solid foods }\end{array}$ & $37(74 \%)$ \\
\hline Dietary diversity $(\mathrm{N}=50)$ & $\begin{array}{l}\text { Feed a variety of foods to ensure that nutrient } \\
\text { needs are met (DDS) }\end{array}$ & $37(74 \%)$ \\
\hline \multirow[t]{2}{*}{ Meal and snack frequency in a day $(\mathrm{N}=50)$} & $\begin{array}{l}\text { Meals should be provided } 2-3 \text { times per day at } \\
6-8 \text { months of age and } 3-4 \text { times per day at } 9-11 \\
\text { and } 12-24 \text { months of age }\end{array}$ & $35(70 \%)$ \\
\hline & $\begin{array}{l}\text { Additional nutritious snacks offered 1-2 times } \\
\text { per day }\end{array}$ & $39(78 \%)$ \\
\hline
\end{tabular}

Table 3. Correlation Between Predisposing Factors with Complementary Feeding Practice

\begin{tabular}{|c|c|c|c|c|c|c|}
\hline \multirow{2}{*}{ Variables } & \multirow{2}{*}{ Category } & \multicolumn{2}{|c|}{ Complementary Feeding Practice } & \multirow{2}{*}{ p value } & \multirow{2}{*}{ OR } & \multirow{2}{*}{$\mathbf{9 5} \% \mathbf{C I}$} \\
\hline & & Less & Good & & & \\
\hline \multirow[t]{2}{*}{ Age of Sitters } & $\leq 21$ years old & $3(6 \%)$ & $3(6 \%)$ & $0.645 \mathrm{a}$ & 1.93 & $0.347-10.77$ \\
\hline & $\geq 21$ years old & $15(30 \%)$ & $29(58 \%)$ & & & \\
\hline \multirow{2}{*}{ Relation with the infants } & Mothers & $15(30 \%)$ & $24(48 \%)$ & $0.724 a$ & 1.67 & $0.38-7.29$ \\
\hline & Alternate sitters & $3(6 \%)$ & $8(16 \%)$ & & & \\
\hline \multirow{2}{*}{ Sitters' education } & $\leq$ Junior high school & $11(22 \%)$ & $8(16 \%)$ & $0.012 \mathrm{bc}$ & 4.71 & $1.36-16.29$ \\
\hline & $>$ Senior high school & $7(14 \%)$ & $24(48 \%)$ & & & \\
\hline \multirow[t]{2}{*}{ Sitters' occupation } & Housewives & $15(30 \%)$ & $26(52 \%)$ & $1.000 \mathrm{a}$ & 1.15 & $0.25-2.65$ \\
\hline & Working mothers & $3(6 \%)$ & $6(12 \%)$ & & & \\
\hline \multirow[t]{2}{*}{ Amount of infants } & $>1$ infants & $7(14 \%)$ & $6(28 \%)$ & $0.738 \mathrm{~b}$ & 0.81 & $0.32-2.84$ \\
\hline & 1 infant & $11(22 \%)$ & $18(36 \%)$ & & & \\
\hline \multirow[t]{2}{*}{ Sitters' knowledge } & Less & $13(26 \%)$ & $10(20 \%)$ & $0.005 b c$ & 5.72 & $1.60-20.44$ \\
\hline & Good & $5(10 \%)$ & $22(44 \%)$ & & & \\
\hline
\end{tabular}

$\mathrm{a}$ : fischer exact test, $\mathrm{b}$ : chi-square test, $\mathrm{c}$ : Significant $(\mathrm{p}$ value $<0.05)$

Table 4. Multivariate Analysis

\begin{tabular}{|c|c|c|c|c|c|c|}
\hline \multirow{2}{*}{ Variables } & \multirow{2}{*}{ Category } & \multicolumn{2}{|c|}{ Complementary Feeding Practice } & \multirow{2}{*}{ p value } & \multirow{2}{*}{ OR } & \multirow{2}{*}{$95 \% \mathrm{CI}$} \\
\hline & & Less n $(\%)$ & Good n (\%) & & & \\
\hline Sitters' education & $\begin{array}{l}\leq \text { Junior high school } \\
>\text { Senior high school }\end{array}$ & $\begin{array}{l}11(22 \%) \\
7(14 \%)\end{array}$ & $\begin{array}{l}8(16 \%) \\
24(48 \%)\end{array}$ & 0.054 & 0.273 & $0.073-1.023$ \\
\hline Sitters' knowledge & $\begin{array}{l}\text { Less } \\
\text { Good }\end{array}$ & $\begin{array}{l}13(26 \%) \\
5(10 \%)\end{array}$ & $\begin{array}{l}10(20 \%) \\
22(44 \%)\end{array}$ & 0.024 & 0.216 & $0.057-0.816$ \\
\hline
\end{tabular}

things related to health, value system adopted by community, education, social economy level, etc; enabling factors that include facilities and infrastructures availability or health's facilities for community; reinforcing factors that include the attitude and behavior of public figures and religious leaders as well as the attitude and behavior of the health workers. ${ }^{21}$ The predisposing factors as analyzed in this study and showed the factors having a significant correlation with complementary feeding practices were sitters' education and knowledge about the complementary food.
Feeding practices among infants at the age of $9-11$ months can be influenced by various factors, such as sitters' education. ${ }^{22}$ A study conducted in Kasihan Subdistrict, Bantul District, Yogyakarta showed that malnutrition among toddlers was significantly correlated with mothers' education $(\mathrm{OR}=0.4 ; 95 \% \mathrm{CI}=0.19$ 0.79). ${ }^{23}$ Based on analysis results, this result was in accordance with the previous study which stated that mother's education had a significant correlation with the complementary feeding practice behavior. Mothers who had low education had prevalence ratio 3.27 times to behave 
poorly compared to those who had higher education ( $p$ value $=0.025) .{ }^{24}$ Mothers with higher education are very likely to be followed by their understanding regarding appropriate responsive feeding on infants. ${ }^{25}$

Likewise, a study conducted in rural Bangladesh found that mothers' education was associated with variables that reflected more intensive care for their children. In a similar study, however, education was also associated with less adequate feeding practices, such as termination of feeding by the mother more often than by the child, a larger number of bottle feeds per day and fewer breastfed per day. The better-educated mothers are more likely to modify their responsive practices to the age of their infants than less-educated mothers do. ${ }^{12}$ In line with study conducted in Indonesia, the result of the study mentioned that mothers with low level of education were less likely to implement appropriate complementary feeding practice. ${ }^{26}$ Results of this study showed that only $58 \%$ of 50 mothers giving continued breastfeeding to their children, the others stopped breastfeeding with various reasons, such as mother had to work and breast milk was not coming out anymore.

Indicators of feeding practice used in this study were based on WHO guidelines of appropriate complementary feeding practices. However, unfortunately, this study only assessed some of them who gave continued breastfeeding, adequate energy intake, consistency of food, dietary diversity, minimum meal and snack frequency, and nutrient intake of the child. The age of nine months is a transitional period to introduce family food, consistency of food during this age gradually increasing from smooth or pureed, mashed or lumpy, then chopped. 27 Most children already met the energy requirement from the complementary feeding, however, low percentage of mothers who continued to breastfeed their children $(58 \%)$ might have influenced the energy intake contributing to malnutrition condition among 9-11 monthold infants.

Knowledge is one of the important factors for feeding practice. ${ }^{12}$ There were four indicators of sitters' knowledge of feeding practices assessed in this study including term of continued breastfeeding, term of complementary feeding, consistency of complementary food and timing of complementary feeding. Sitters had good knowledge of continued breastfeeding if they answered. Term of continued breastfeeding is continuing breastfeeding after exclusive breastfeeding period. Sitters had good knowledge of complementary feeding if they answered, food given to the six month-old infants to complement the breast milk. Moreover, based on the stage of age, at the age of six months, more children were given liquid food. At the age of nine months, more children were given semi-solid food. Then at age of 12 months, more children were given solid food.
This study found that even most sitters had high education, they did not know about the terminology of continued breastfeeding. They knew about the term and appropriate food consistency of complementary feeding, but they did not know about the appropriate time to give the complementary food to the children. Knowledge of complementary feeding practice was related to mothers' education.

From the interview, it was known that respondents' knowledge regarding the age of the infants that were able to be given food or drink other than breast milk or family food was still poor. Low general knowledge concerning on infants' food may lead to undernutrition among infants. The fact showed that mothers who still breastfed their infants assumed that breast milk could meet infants' needs until they could submit a request to feed themselves (approximately at 12 months old). After the infants were 12 months old, they should know the family food. Respondents' knowledge concerning on the consequence of early complementary feeding on infants were still poor as well. The common growth disorder problem among toddlers had strength allegedly related to many infants who were already given complementary food since one month old, even before that. Early weaning food can increase allergies and infection, then complementary feeding on infants even before three months old will increase respiratory infection risk and marginally increase eye infection risk and episodes of malaria. ${ }^{27,28}$

Meanwhile, Tucker and Sanjur said 12 that maternal differentiation was positively associated with children's dietary intake and anthropometric status in their study. They used 'maternal differentiation' rather than mothers' education in their analysis of correlation of child nutrition in Panama. Maternal differentiation is a composite variable that incorporates not only years of education, but also current nutritional knowledge, frequency of reading and measure of household productivity. Thus, this measure includes evidence of use and retention of information, which they feel that it is theoretically more coherent than merely using years of schooling. Meanwhile, the previous study, which is in line with this study, proved that mothers who had poor knowledge would have risk 2.9 times higher to have poor behavior on balanced diet feeding on toddlers compared to the ones with good knowledge. ${ }^{29}$ Mothers' education affects care-giving practices, such as ability to process information, acquire skills and model behavior. ${ }^{12}$ Mothers' education factor might contribute sitters to probe information about feeding practice more actively. In Indonesia, high education level of mothers and fathers were both associated with protective care-giving behaviors. ${ }^{22}$

Most sitters in the study were housewives (64\%), which means that most children were taken care of by their own mothers, which might be related to good feed- 
ing practices among them. A few recent studies found significant negative associations of work for earnings with child's nutritional status. In an evaluation of almost 2,000 rural mothers in India, children of mothers who worked in agricultural sector on their own farms for five to six hours per day were likely to be significantly malnourished regardless of who the alternate sitter was. ${ }^{12}$

\section{Conclusion}

Predisposing factors correlated with complementary feeding are sitters' education and knowledge concerning on complementary feeding, meanwhile predisposing factors not significantly correlated are sitters' age, relation between the infants and their sitters, sitters' occupation and number of infants. Low education and inadequate knowledge of appropriate food and feeding practices are a greater predisposing factor regarding the complementary feeding practices among $9-11$ month-old infants.

\section{Acknowledgement}

The authors are grateful to the cadres and field team, also thank the sitters and $9-11$ month-old infants for their participation in this study.

\section{References}

1. United States Agency for International Development. Indicators for assessing infant and young child feeding practices part III. Geneva: World Health Organization; 2010.

2. World Health Organization. Children-reducing mortality [online]. 2010 [cited 2015 Jun 5]. Available from: http://www.who.int/mediacentre/ factsheets/fs178/en/index.html

3. Kementerian Kesehatan Republik Indonesia. Riset kesehatan dasar tahun 2010. Jakarta: Kementerian Kesehatan Republik Indonesia; 2010.

4. World Health Organization. Guiding principles for complementary feeding of the breastfed child. Geneva: World Health Organization; 2001.

5. United States Agency for International Development. Infant and young child feeding update. Calverton: ORC Macro; 2006.

6. United States Agency for International Development. Indicators for assessing infant and young child feeding practices part I. Geneva: World Health Organization, 2008.

7. World Health Organization. Guiding principles for feeding non-breast fed children 6-24 months of age. Geneva: World Health Organization; 2005.

8. Dewey KG, Piwoz EG, Pelto GH, Lutter CK, Mensah P, Daelman B. Contents on complementary feeding and implications for intervention programs. In: Daelmans B, Martines J, Saadeh R, Dewey KG, Brown $\mathrm{KH}$, editors. Special issued based on a World Health Organization expert consultation on complementary feeding. Geneva: World Health Organization; 2003. p. 144.

9. Black RE, Allen LH, Bhutta ZA, Caulfield LE, de Onis M, Ezzati M, et al. Maternal and child undernutrition: global and regional exposures and health consequences. Lancet [serial on internet]. 2008 Jan 19 [cited 2012 Mar 11]; 371 (9608): 243-60. Available from: http://www.ncbi.nlm.nih.gov/pubmed/18207566.
10. United Nation International Children's Funding. The State of the World's Children. Oxford: Oxford University Press; 1998.

11. Kumar D, Goel NK, Mittal PC, Misra P. Influence of infant-feeding practices on nutritional status of under-five children. Indian Journal of Pediatrics. 2006; 73 (5): 417-22.

12. Engle PL, Menon P, Haddad L. Care and nutrition concept and measurement. Washington DC: International Food Policy Research Institute; 1997.p. 60.

13. Ng CS, Dibley MJ, Agho KE. Complementary feeding indicators and determinants of poor feeding practices in Indonesia: a secondary analysis of 2007 Demographic and Health Survey data. Public Health Nutrition. 2012; 15 (5): 827-39.

14. Inayati DA, Scherbaum V, Purwestri RC, Hormann E, Wirawan NN, Suryantan J, et al. Infant feeding practices among mildly wasted children: a retrospective study on Nias Island, Indonesia. International Breastfeeding Journal. 2012 Jan; 7 (1): 3.

15. Dewey KG. Nutrition, growth, and complementary feeding of the breastfed infant. Pediatrics of Clinic North America. $2001 \mathrm{Feb}$; 48 (1): 87-104.

16. World Health Organization. Complementary feeding of young children in developing countries? a review of current scientific knowledge. Geneva: World Health Organization; 1998.

17. Dewey KG, Brown KH. Update on technical issues concerning complementary feeding of young children in developing countries and implications for intervention programs. Food and Nutrition Bulletin. 2003 Mar; 24 (1): 5-28.

18. Gibson RS, Ferguson EL, Lehrfeld J. Complementary foods for infant feeding in developing countries: their nutrient adequacy and improvement. European Journal of Clinical Nutrition [serial on internet]. 1998 Oct [cited 2015 Jan 5]; 52 (10): 764-70. Available from: http://www.ncbi.nlm.nih.gov/pubmed/9805226

19. Ahmad A, Boediman D, Prawirohartono EP. Pola makanan pendamping air susu ibu dan status gizi bayi 0-12 bulan di Kecamatan Lhoknga Kabupaten Aceh Besar. Jurnal Gizi Klinik Indonesia. 2006; 3 (1): 1-8.

20. Dickin K, Griffiths M, Piwoz E. Designing by dialogue a program planners' guide to consultative for improving young child feeding. Connecticut: support for analysis and research in Africa; 1997.

21. Notoatmodjo S. Promosi kesehatan dan ilmu perilaku. Jakarta: PT Rineka Cipta; 2007.

22. Semba RD, Pee S De, Sun K, Sari M, Akhter N, Bloem MW. Effect of parental formal education on risk of child stunting in Indonesia and Bangladesh: a cross-sectional Study. Lancet. 2008; 371: 322-8.

23. Kuntari T, Jamil NA, Kurniati O. Malnutrition risk factor for under five years. Kesmas: Jurnal Kesehatan Masyarakat Nasional. 2013; 7 (12): $572-6$.

24. Rosnah. Faktor-faktor yang berhubungan dengan perilaku ibu dalam pemberian makanan pendamping ASI (MP-ASI) pada anak usia 6-24 bulan di Puskesmas Perumnas Kecamatan Kadia Kota Kendari [thesis]. Yogyakarta: Universitas Gadjah Mada; 2007.

25. Haku M. Breastfeeding: factors associated with the continuation of breastfeeding, the current situation in Japan, and recommendations for further research. The Journal of Medical Investigation. 2007; 54 (10): 224-34.

26. Senarath U, Agho KE, Akram DS, Godakandage SSP, Hazir T, Jayawickrama $\mathrm{H}$, et al. Comparisons of complementary feeding indica- 
tors and associated factors in children aged 6-23 months across five South Asian countries. Maternal and Child Nutrition [serial on internet]. 2012 Jan [cited 2012 Jun 2]; 8 Suppl 1: 89-106. Available from: http://www.ncbi.nlm.nih.gov/pubmed/22168521

27. British Nutrition Foundation. Weaning your baby FAQ [internet]. 2015 [cited 2015 Jan 5]. Available from: http://www.nhs.uk/ipgmedia/ National/British Nutrition Foundation/assets/Weaningyourbaby.pdf 28. Kalanda BF, Verhoeff FH, Brabin BJ. Breast and complementary feeding practices in relation to morbidity and growth in Malawian infants. European Journal of Clinical Nutrition [serial on internet]. 2006 [cited 2015 Jan 5]; 60: 401-7. Available from: http://www.nature.com/ doifinder/10.1038/sj.ejen.1602330

29. Rusmimpong. Faktor yang berhubungan dengan perilaku ibu dalam pemberian makan gizi seimbang pada balita di wilayah Puskemas Kenali Besar Kota Jambi [thesis]. Yogyakarta: Universitas Gadjah Mada; 2007. 